\title{
RAPIDLY ARRIVING FUTURES: FUTURE READINESS FOR INDUSTRY 4.0
}

\author{
A.P. Botha ${ }^{1,2 *}$
}

\section{ARTICLE INFO}

Article details

Presented at the $29^{\text {th }}$ annual conference of the Southern African Institute for Industrial Engineering (SAIIE), held from 24-26 October 2018 in Stellenbosch, South Africa

Available online 9 Nov 2018

\section{Contact details}

Corresponding author anthon@technoscene.co.za

Author affiliations

1 Department of Engineering and Technology Management, University of Pretoria, South Africa

2 TechnoScene (Pty) Ltd, South Africa

DOI

http://dx.doi.org/10.7166/29-3-2056

\section{ABSTRACT}

The future being shaped by Industry 4.0 has arrived. Tools are available that anticipate the future, approximate it, estimate it, and select a preferred future; but do we know how to make disruptive futures part of our business and lives? Building on technology readiness levels and manufacturing readiness levels, future readiness levels and a future readiness index are suggested in this paper. The future readiness levels (FRL) are based on readiness at the capability levels of technology, behaviour, event, and future thinking. A future readiness index (FRI) is then determined, based on the entire future thinking space (technology, behaviour, events, and capability to do future thinking). Once the FRL and FRI are known, it will become clear what strategic interventions are required to thrive in a preferred future. The existing and desired situations in future readiness are compared, and the gaps are addressed. This approach provides a tool for the internal monitoring and evaluation of the state of the organisation to remain sustainable and competitive in a future that is fast arriving; to compare organisations competitively in a similar cluster; to benchmark at industry level; and ultimately to have the potential to measure the future readiness of nations.

\section{OPSOMMING}

Die toekoms wat deur Industrie 4.0 bepaal word, het aangebreek. Metodes is beskikbaar om die toekoms te antisipeer, dit te benader, dit af te skat en 'n gekose toekoms te kies; maar weet ons hoe om ontwrigtende toekomste deel van ons besigheid en lewens te maak? Deur voort te bou op tegnologiegereedheidsvlakke en vervaardigingsgereedheidsvlakke, word toekomsgereedheidsvlakke en 'n toekomsgereedheidsindeks in die artikel voorgestel. Toekomsgereedheid is gebaseer op gereedheid op die tegnologie, gedrag, gebeurtenis en vermoë tot toekomsdenke vlakte. Die gereedheidsindeks word bepaal deur die totale toekomsdenke ruimte. Wanneer die gereedheidsmetings beskikbaar is, kan daar op strategiese ingryping besluit word, wat sukses in die toekoms sal bepaal. Bestaande en verlangde toekomsgereedheid kan bepaal word en die gapings tussen hierdie toestande kan aangespreek word. Die benadering verskaf ' $n$ metode vir interne monitering en evaluering van die toestand van die organisasie wat dit in staat stel om kompeterend te bly in ' $n$ toekoms wat vinning naderkom, om kompeterende vergelyking te doen van organisasies in soortgelyke besigheid, om op industrievlak te vergelyk, sowel as om, uiteindelik, na die toekomsgereedheid van nasies te kyk. 
Industry 4.0 can be classified as a rapidly arriving future. Until recently, it was a phenomenon of the distant future; but in the past three years it has been taken up in many facets of the manufacturing and service industry value chains. During the introduction phase, various definitions of Industry 4.0 have been provided, with two interesting ones quoted here: "end-to-end digitisation of all physical assets and integration into digital ecosystems with value chain partners" [1], and "all digitally enabled disruptive technologies that are likely to have a significant impact on manufacturing within the next 10 years" [2]. While newly adopted Industry 4.0 principles and processes may still be conceptualised, and agreement on exactly what is required to be successful has not been reached, strategies for Industry 4.0 are the order of the day. Strategic planning has been supported by tools such as technology readiness levels (TRLs) [3] and manufacturing readiness levels (MRLs) [4]. The question arises: How can one be future-ready, specifically for Industry 4.0? This is a thought-leading paper in which a conceptual model for future readiness is proposed. This model manifests itself in suggested future readiness levels (FRLs) and a future readiness index (FRI).

\section{BACKGROUND AND LITERATURE}

\subsection{Fourth Industrial Revolution maturity models}

Several Industry 4.0 maturity models have been suggested in the literature [5]. These include dimensions of:

- $\quad$ strategy and organisation, smart factory, smart operations, smart products, data-driven services, and employees [6]

- $\quad$ a process model for the realisation of Industry 4.0, gap analyses, and a toolbox for overcoming maturity barriers

- $\quad$ an on-line self-assessment tool for understanding Industry 4.0

- a connected enterprise maturity model, based on a five-stage approach to realise Industry 4.0 - viz., assessment, secure and upgraded network and controls, defined and organised working data capital, analytics, and collaboration [7].

The maturity model proposed by Schumacher, Erol and Sinn [5] includes dimensions of strategy, leadership, customer, products, operations, culture, people, governance, and technology. Most of these approaches depend on the notion of a maturity model and not on an assessment of readiness. Maturity, in applying a new paradigm such as Industry 4.0, can only be achieved once there has been consistent operation in the environment for a considerable time. Industry 4.0 is just too young for that. This is why the focus in this paper is shifting to readiness measurement, where an assessment of readiness can be made for aspects of a new future that is still arriving, often at a rapid pace. This type of measurement is done within the framework of future thinking.

\subsection{Future thinking}

The future cannot be predicted, yet it is also not pre-determined. Future thinking is an integrated and holistic approach that looks at the future and what opportunity it holds [8-11]. It addresses four levels of futures: a possible future, a plausible future, a probable future, and a preferred future. It is aimed at strategic visioning, and includes the methodology of back-casting to determine strategic interventions in the present to manage the present from the future. Future thinking processes look at the future in the context of future shaping factors: technology (not science fiction, but technologies that are recognisable in the research and development phase); the behaviour of people (in the marketplace and workplace); and events that change the world (geopolitical events, natural events, economic events, and demographic and social shifts - predictable and unpredictable, avoidable and unavoidable). A triangle spanned by technology, behaviour, and events is drawn as a future thinking space (Figure 1). The relevance of the future-shaping factors is determined by their impact and probability; and the factors are categorised as emerging (high probability, low impact), disruptive (high probability, high impact), wild cards (low probability, high impact), and weak signals (low probability, low impact). This thought model is used to determine inter-factor influences that lead to scenarios of multiple futures. A preferred future can be selected, and a strategy can be shaped to reach that desired state in the future. 


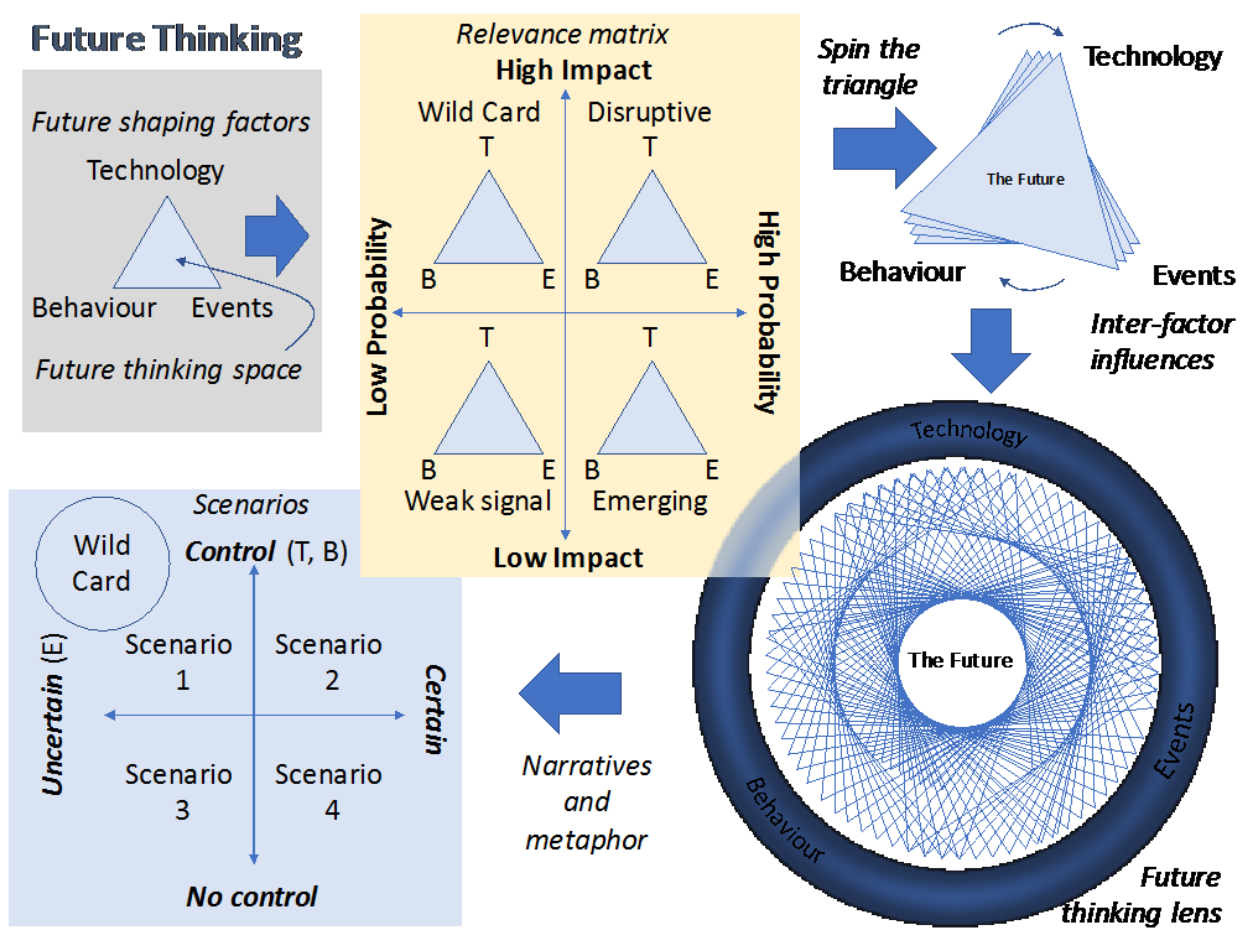

Figure 1: The future thinking process (Source: [8 - 11])

\subsection{Readiness levels}

The use of technology readiness levels and manufacturing readiness levels has been accepted technology and engineering management practice for some time [12]. These levels are still being developed, and recently, a tenth technology readiness level was added by NASA [13]. A summary of the accepted technology readiness levels used at present is shown in Figure 2.

\begin{tabular}{|c|l|}
\hline TRL & \multicolumn{1}{|c|}{ Description } \\
\hline 10 & Proven operations \\
\hline 9 & System operational \\
\hline 8 & Subsystem build and test \\
\hline 7 & Detailed design and assembly level build \\
\hline 6 & Preliminary design and prototype validation \\
\hline 5 & Conceptual design and prototype demonstration \\
\hline 4 & Technology demonstration \\
\hline 3 & Proof-of-concept \\
\hline 2 & Technology concept \\
\hline 1 & Technology research \\
\hline
\end{tabular}

Figure 2: Technology readiness levels used in technology management (Source: [13])

Although the scale of the levels may be described as moving towards maturity, it is argued in this paper that maturity measurement can only begin once proven operations have been demonstrated.

Likewise, a scale of manufacturing readiness levels [4] is provided in Figure 3. 


\begin{tabular}{|c|l|}
\hline MRL & \multicolumn{1}{|c|}{ Description } \\
\hline 10 & $\begin{array}{l}\text { Full rate production demonstrated and lean production practices } \\
\text { in place }\end{array}$ \\
\hline 9 & $\begin{array}{l}\text { Low rate production demonstrated; capability in place to begin } \\
\text { full rate production }\end{array}$ \\
\hline 8 & $\begin{array}{l}\text { Pilot line capability demonstrated; ready to begin low rate Initial } \\
\text { production }\end{array}$ \\
\hline 7 & $\begin{array}{l}\text { Capability to produce systems, subsystems, or components in a } \\
\text { production representative environment }\end{array}$ \\
\hline 6 & $\begin{array}{l}\text { Capability to produce a prototype system or subsystem in a } \\
\text { production relevant environment }\end{array}$ \\
\hline 5 & $\begin{array}{l}\text { Capability to produce prototype components in a production } \\
\text { relevant environment }\end{array}$ \\
\hline 4 & Capability to produce the technology in a laboratory environment \\
\hline 3 & Manufacturing proof of concept developed \\
\hline 2 & Manufacturing concepts Identified \\
\hline 1 & Basic manufacturing implications identified \\
\hline
\end{tabular}

Figure 3: Manufacturing readiness levels used in technology management (Source: [4])

The MRLs are inherently dependent on the TRLs, since manufacturing technology is applied. The question arises: How do these readiness levels hold in Industry 4.0, and how should they be supported by a future readiness measurement for a rapidly approaching paradigm shift in many industries?

\section{RESEARCH METHODOLOGY}

In this research, FRLs and an FRI were postulated and tested with a group of respondents who work in industries or policy environments where Industry 4.0 has already made an impact. The respondents were asked to validate the FRLs suggested, and to place them in the context of the future thinking approach and the rapidly deploying Industry 4.0. The respondents were also asked to comment on a future readiness audit, measurement methodology, and process, as well as maturity levels for future thinking capability. The results were analysed and conclusions were derived from the synthesis.

\section{CONCEPTUAL FUTURE READINESS MODEL}

Building on TRLs, MRLs, and capability maturity models (CMMS), future readiness levels (FRLs) and a future readiness index (FRI) are proposed. The FRLs are based on readiness at the technology, behaviour, and event dimensions of the future thinking space and future thinking capability. A set of future readiness levels has been defined for each of the future shaping factors (technology, behaviour, events), and for future thinking capability. A methodology to conduct a future readiness audit and assessment is suggested. In the calculation of this rating, the importance of an FRL is determined and the state of its implementation is quantified. A future readiness factor (percentage readiness) is subsequently calculated. An FRI is then provided, based on the contribution of these individual future readiness factors for the entire future thinking space and the future thinking capability. This approach provides a tool for the internal monitoring and evaluation of the state of the organisation to remain sustainable and competitive in a future that is fast arriving; to compare organisations competitively in a similar cluster; to benchmark at industry level; and ultimately to have the potential to measure the future readiness of nations.

\subsection{Future readiness levels (FRLs)}

The following FRLs were postulated and tested among respondents. The levels indicated were all deemed essential to the model, and are arranged in order of the achievement necessary to proceed upward on the readiness scale.

\subsubsection{Technology future readiness levels (TFRLs)}

The TFRLs shown in Figure 4 are based on the technology management approaches that are required for emerging, disruptive, wild card, or weak signal technologies in a specific environment - in the case of this paper, for Industry 4.0. 


\begin{tabular}{|c|l|}
\hline TFRL & \multicolumn{1}{|c|}{ Description } \\
\hline 10 & Disruptive technology incorporated in business \\
\hline 9 & Technology life cycle management practised \\
\hline 8 & Technology adoption measured \\
\hline 7 & Technology vision in place \\
\hline 6 & Technology evaluation conducted \\
\hline 5 & Technology roadmapping practised \\
\hline 4 & Technology assessment (impact on humans) done \\
\hline 3 & Technology foresighting practised \\
\hline 2 & Technology trend-spotting in place \\
\hline 1 & Technology scanning mechanisms in place \\
\hline
\end{tabular}

Figure 4: Technology future readiness levels

\subsubsection{Behaviour future readiness levels (BFRLs)} Market behaviour future readiness levels

\begin{tabular}{|c|l|}
\hline BFRL & \multicolumn{1}{|c}{ Description } \\
\hline 5 & Influencing market adoption patterns \\
\hline 4 & Predicting needs of future customers/clients \\
\hline 3 & Adopting new transactional methods \\
\hline 2 & Understanding generational market influence \\
\hline 1 & Keeping pace with fast changing consumer/client expectations \\
\hline
\end{tabular}

Figure 5: Market behaviour future readiness levels

The BFRLs shown in Figure 5 are related to the behaviour that is external to the enterprise and focused on the market. It addresses the user revolution, market dynamics, and adoption patterns, among others.

\section{Enterprise behaviour future readiness levels}

\begin{tabular}{|c|l|}
\hline BFRL & \multicolumn{1}{|c}{ Description } \\
\hline 5 & Human-machine harmony in place \\
\hline 4 & Co-ordinate-and-cultivate leadership style adopted \\
\hline 3 & Liberated approach towards the workspace evident \\
\hline 2 & Social network analysis in place and practised \\
\hline 1 & Ability to resource and manage a balanced generation mix \\
\hline
\end{tabular}

Figure 6: Enterprise behaviour future readiness levels

In Figure 6, BFRLs relating to the behaviour inside enterprises are shown. These refer to the changing demographics in the workplace, the work space, and the inevitable interaction between humans and intelligent machines in Industry 4.0.

\subsubsection{Event future readiness levels (EFRLs)}

Figure 7 indicates EFRLs that are deemed necessary to become future ready. They address the ability to do event spotting, and to make sense of the emergence of these events. The ability to position business within the context of these events is critical.

\subsubsection{Future thinking readiness levels (FTRLs)}

The ability to do proper future thinking contributes to the level of readiness for the future. These aspects, highlighted and sequenced in Figure 8 , deal with future thinking skills that have been identified as essential [8-11] and the methodology and approach provided in Figure 1 . The ability at the various levels is measured in terms of the adoption of future thinking skills that individuals develop through exposure to future thinking methods, and their application of these methods in dayto-day tasks. 


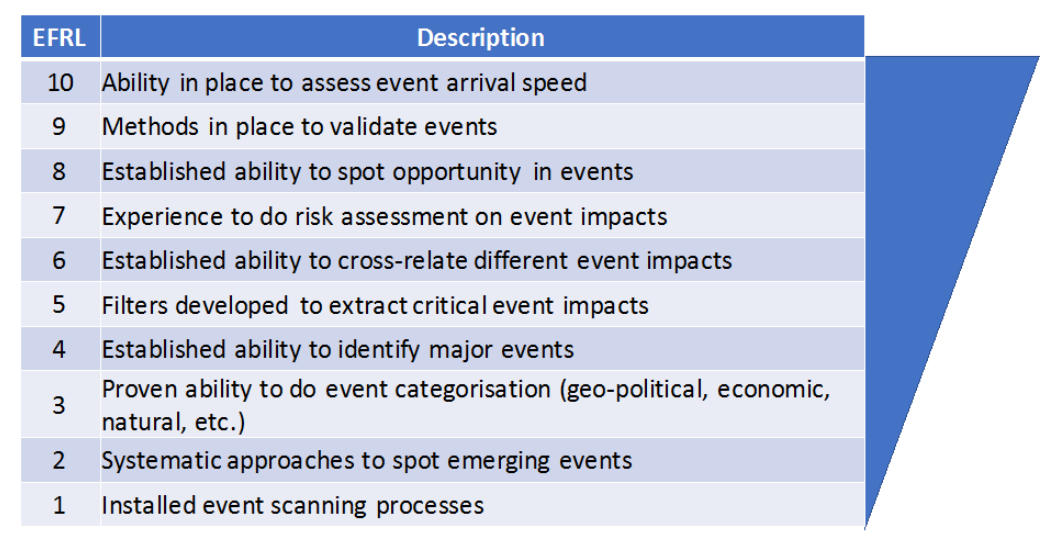

Figure 7: Event future readiness levels

\begin{tabular}{|c|l|}
\hline FTRL & \multicolumn{1}{|c}{ Description } \\
\hline 10 & Ability to extract likely and preferred futures \\
\hline 9 & Ability to develop narratives and visualisation of the future \\
8 & Ability to do scenario planning \\
7 & Ability to determine higher order impacts of disruptive factors \\
\hline 6 & $\begin{array}{l}\text { Ability to determine inter-factor influences between technology, } \\
\text { behaviour and events }\end{array}$ \\
\hline 5 & $\begin{array}{l}\text { Ability to identify emerging, disruptive, wild card and weak signals } \\
\text { in the future shaping factors }\end{array}$ \\
\hline 4 & $\begin{array}{l}\text { Ability to determine relevance (impact and probability) of future } \\
\text { shaping factors }\end{array}$ \\
\hline 3 & $\begin{array}{l}\text { Ability to identify technology, behaviour and event factors that } \\
\text { shape the future thinking space }\end{array}$ \\
\hline 2 & Ability to apply mind-time travel between past, present and future \\
\hline 1 & Ability to do anticipatory thinking \\
\hline
\end{tabular}

Figure 8: Future thinking readiness levels

\subsection{FRL audit and assessment}

With a preferred future constructed or a disruptive one dawning, the next question is: How will the readiness of the preferred future be measured using the readiness levels mentioned above? The answer lies in a future readiness audit, and using the audit units of measurement to construct a visual representation of future readiness.

\subsubsection{FRL audit}

The following questions are important in a future readiness audit:

- Do we know what the activities in our organisation are to sustain the future readiness level in our organisation?

- $\quad$ Can we identify the location within the organisation where the activities take place?

- Do we know the scale of the activities that enable our future readiness levels (organisationwide; departmental; group; individual)?

- $\quad$ Can we identify the documents/procedures/policies that give evidence of our future readiness levels?

- $\quad$ Can we name individuals who have responsibility for upholding the future readiness level?

\subsubsection{Future readiness mapping}

The matrix presented in Table 1, consisting of the FRLs and the audit units of measurement, form a mapping of the future readiness. They should be populated with the information for the organisation by: 
a. Listing activities that are in place

b. Pinpointing the location(s) of the activities within the organisation

c. Stating the scale of the activities related to the future readiness levels

d. Listing all relevant documents (strategies, policies, reports, white papers, minutes, guidelines, rules, etc.)

e. Listing the names and contact details of individuals involved in the activities, their location, responsibilities, authority, etc.

This matrix is completed following preparation by the organisation of a detailed breakdown of the strategies, policies, processes, and documents in the organisation that need to be included in the audit and assessment, as well as identifying the activities, location, and individuals that are critical to these readiness levels. A summary is shown in Table 1.

Table 1: Example of a future readiness matrix

\begin{tabular}{|c|c|c|c|c|c|c|}
\hline FRL & $\begin{array}{c}\text { Readiness } \\
\text { expression }\end{array}$ & Activities & Location & Scale & Documents & Individuals \\
\hline $\begin{array}{c}\text { TFRLs } \\
\text { (all to be listed) }\end{array}$ & (from Fig 4) & $\begin{array}{c}\text { Refer to (a) } \\
\text { above }\end{array}$ & $\begin{array}{c}\text { Refer to (b) } \\
\text { above }\end{array}$ & $\begin{array}{c}\text { Refer to (c) } \\
\text { above }\end{array}$ & $\begin{array}{c}\text { Refer to (d) } \\
\text { above }\end{array}$ & $\begin{array}{c}\text { Refer to (e) } \\
\text { above }\end{array}$ \\
\hline $\begin{array}{c}\text { BFRLs } \\
\text { (all to be listed) }\end{array}$ & (from Fig 5 \& 6) & $\begin{array}{c}\text { Refer to (a) } \\
\text { above }\end{array}$ & $\begin{array}{c}\text { Refer to (b) } \\
\text { above }\end{array}$ & $\begin{array}{c}\text { Refer to (c) } \\
\text { above }\end{array}$ & $\begin{array}{c}\text { Refer to (d) } \\
\text { above }\end{array}$ & $\begin{array}{c}\text { Refer to (e) } \\
\text { above }\end{array}$ \\
\hline EFRLs & (from Fig 7) & $\begin{array}{c}\text { Refer to (a) } \\
\text { above }\end{array}$ & $\begin{array}{c}\text { Refer to (b) } \\
\text { above }\end{array}$ & $\begin{array}{c}\text { Refer to (c) } \\
\text { above }\end{array}$ & $\begin{array}{c}\text { Refer to (d) } \\
\text { above }\end{array}$ & $\begin{array}{c}\text { Refer to (e) } \\
\text { above }\end{array}$ \\
\hline FTRLs listed) & (from Fig 8) & $\begin{array}{c}\text { Refer to (a) } \\
\text { above }\end{array}$ & $\begin{array}{c}\text { Refer to (b) } \\
\text { above }\end{array}$ & $\begin{array}{c}\text { Refer to (c) } \\
\text { above }\end{array}$ & $\begin{array}{c}\text { Refer to (d) } \\
\text { above }\end{array}$ & $\begin{array}{c}\text { Refer to (e) } \\
\text { above }\end{array}$ \\
\hline
\end{tabular}

\subsubsection{FRL assessment}

The understanding that follows from the audit and mapping of future readiness units of measurement is then applied, and a rating is provided for the importance (high, medium or low; or any other chosen scale) of any particular level for the enterprise for which the future readiness assessment is done, and the state of readiness (ready, in progress, unprepared, or another chosen scale) based on the audit and mapping. This assessment, using the relative scores for the various levels, is then done in the enterprise and among its external stakeholders (shareholders, clients, suppliers, partners, influencers, facilitators, etc.). These are all entities upholding the future readiness. The calibration of the scales is up to the organisation or its industry in which it operates. For benchmarking, there needs to be conformity; for internal measurement, performance indicators are agreed that can be measured, or consensus is reached. The outcome of the assessment is illustrated in Table 2.

Table 2: FRL assessment

\begin{tabular}{|c|c|c|c|}
\hline FRL & $\begin{array}{c}\text { Readiness } \\
\text { expression }\end{array}$ & Importance & State \\
\hline $\begin{array}{c}\text { TFRLs } \\
\text { (all to be listed) }\end{array}$ & (from Fig 4) & $\begin{array}{c}\text { High, } \\
\text { medium, or } \\
\text { low }\end{array}$ & $\begin{array}{c}\text { Ready, } \\
\text { in progress, } \\
\text { unprepared }\end{array}$ \\
\hline $\begin{array}{c}\text { BFRLs } \\
\text { (all to be listed) }\end{array}$ & (from Fig 5 \& 6) & $\begin{array}{c}\text { High, } \\
\text { medium, or } \\
\text { low }\end{array}$ & $\begin{array}{c}\text { Ready, } \\
\text { in progress, } \\
\text { unprepared }\end{array}$ \\
\hline $\begin{array}{c}\text { EFRLs } \\
\text { (all to be listed) }\end{array}$ & (from Fig 7) & $\begin{array}{c}\text { High, } \\
\text { medium, or } \\
\text { low }\end{array}$ & $\begin{array}{c}\text { Ready, } \\
\text { in progress, } \\
\text { unprepared }\end{array}$ \\
\hline $\begin{array}{c}\text { FTRLs } \\
\text { (all to be listed) }\end{array}$ & (from Fig 8) & $\begin{array}{c}\text { High, } \\
\text { medium, or } \\
\text { low }\end{array}$ & $\begin{array}{c}\text { Ready, } \\
\text { in progress, } \\
\text { unprepared }\end{array}$ \\
\hline
\end{tabular}

Visualisations of the outcome of the future readiness assessment, in the form of radar diagrams, are given in Figure 9 to Figure 12.

The ratings are done on a relative scale from 0 to 3 . The assessment of the ratings is based on an external benchmark, or on an internally defined scale that can be measured, or when consensus is reached on the status vs the ideal.

The importance levels should all remain at maximum if a benchmark is to be done among various divisions in the enterprise or industry. It may, however, be possible for the importance of the FRLs to vary in an environment where the future readiness assessment is being introduced. Such a case for the BFRLs is shown in Figure 10. 
An example of the EFRL assessment is shown in Figure 11.

This visual representation provides a quick view of where the gaps are for improvement that can be addressed through strategic or policy intervention. It reveals the future readiness levels that need attention for improvement. By repeating this exercise in the enterprise, monitoring and evaluation of the progress towards future readiness can be established.

An illustration of the state of future readiness in future thinking capability is shown in Figure 12.

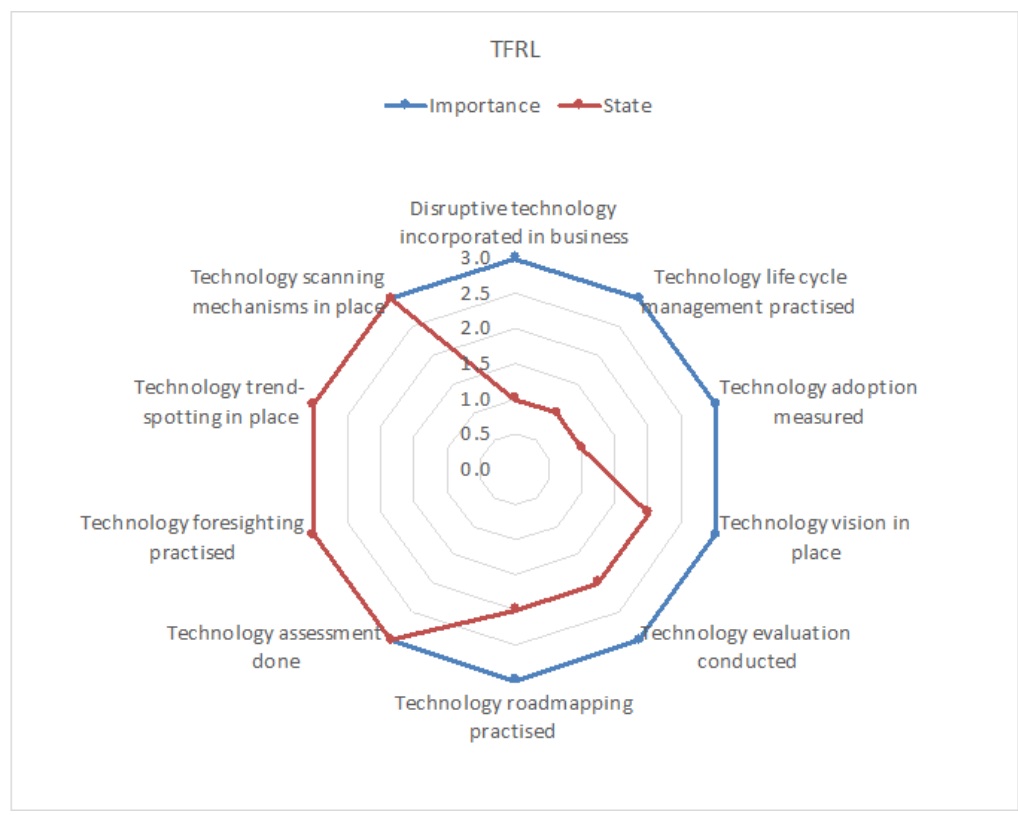

Figure 9: Illustration of the state of future readiness based on TFRLs for an enterprise, following an FRL assessment (all importance levels at maximum) (see online version for colour)

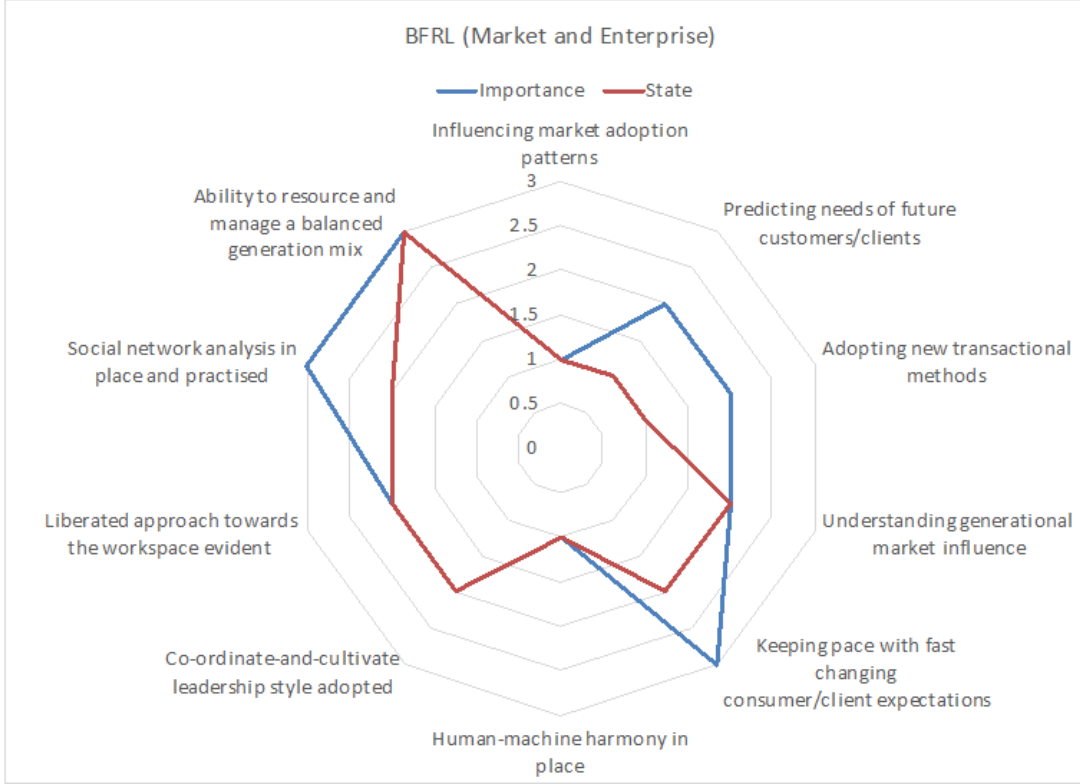

Figure 10: Illustration of the state of future readiness based on BFRLs for an enterprise (market - external and enterprise - internal), following an FRL assessment (importance levels varying) (see online version for colour) 


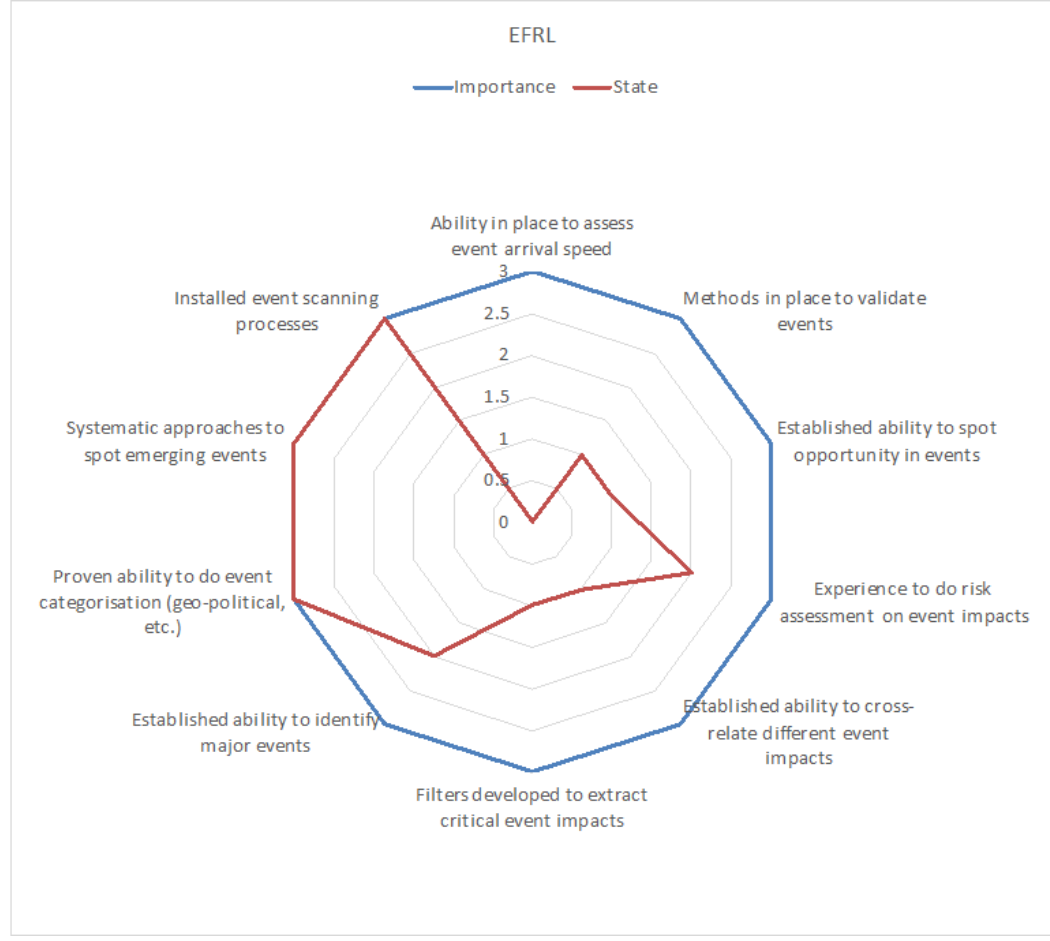

Figure 11: Illustration of the state of future readiness based on EFRLs for an enterprise, following an FRL assessment (all importance levels at maximum) (see online version for colour)

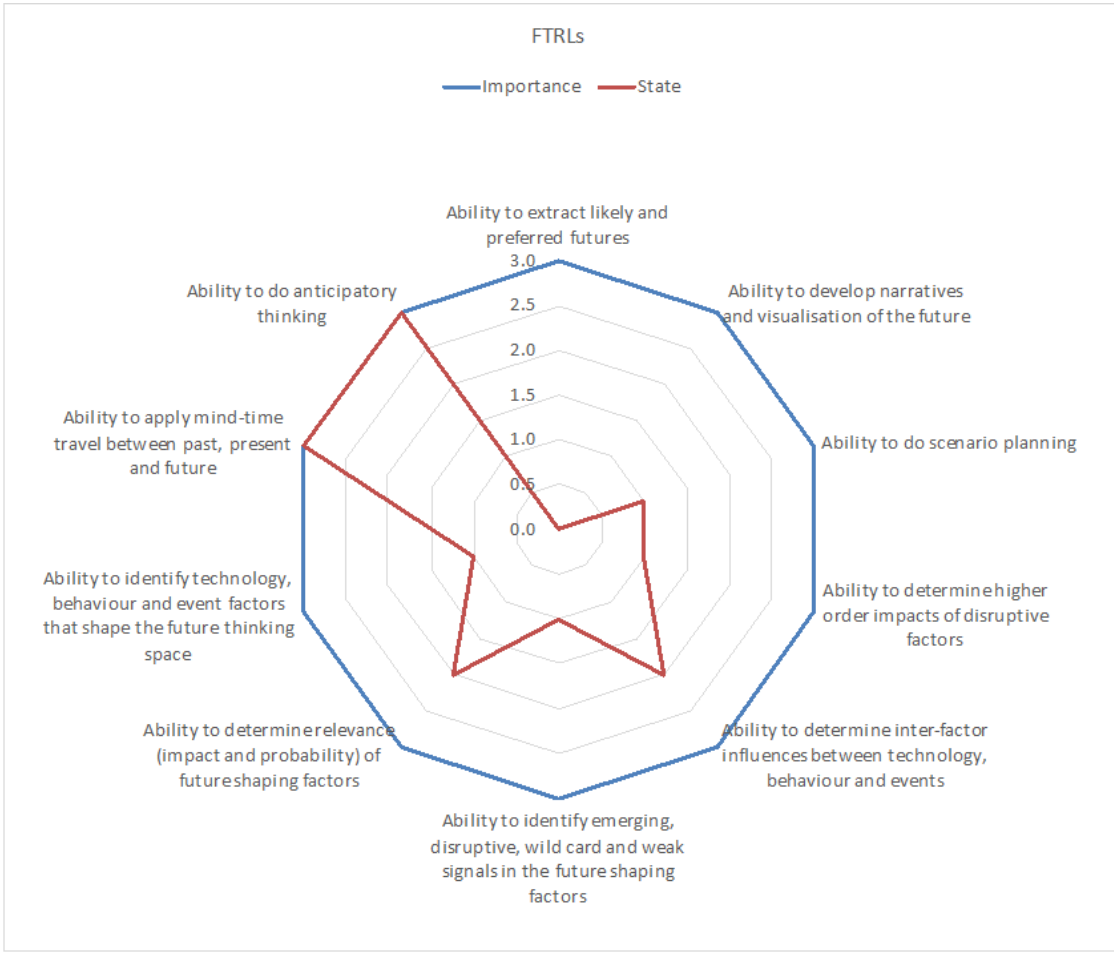

Figure 12: Illustration of the state of future readiness based on FTRLs for an enterprise, following an FRL assessment (all importance levels at maximum) (see online version for colour) 


\subsection{Future readiness index (FRI)}

Once all the FRL assessments for the future shaping factors and future thinking capability have been done, an integrated view of the state of future readiness is possible. This is expressed through a future readiness index (FRI). The FRI is calculated as an average of the outcomes of the TFRLs, BFRLs, EFRLs, and FTRLs. An illustration is given in Table 3.

Table 3: Calculating the FRI from the overall FRL outcomes

\begin{tabular}{|c|c|c|}
\hline FRL & $\begin{array}{c}\text { \% Readiness } \\
\text { (first assessment) }\end{array}$ & $\begin{array}{c}\text { \% Readiness } \\
\text { (second assessment) }\end{array}$ \\
\hline TFRL & 70 & 90 \\
\hline EFRL & 57 & 80 \\
\hline FTRL & 47 & 75 \\
\hline BFRL & 63 & 70 \\
\hline FRI & 59 & 79 \\
\hline
\end{tabular}

To monitor progress towards improved future readiness, regular future readiness audits and assessments can be done. The outcomes of the first assessment are then compared with those of subsequent assessments, and the direction and speed of change of the FRI are used to intervene strategically to push the enterprise to the desired level of future readiness. The same can be done for an industry or a nation. This makes the FRI an equivalent parameter to an R\&D index, an innovation index, or a competitive index.

Figure 13 illustrates the visualisation of an FRI that was measured using the examples given above, and a subsequent one to indicate growth along the FRL dimensions.

\section{Overall Future Readiness}

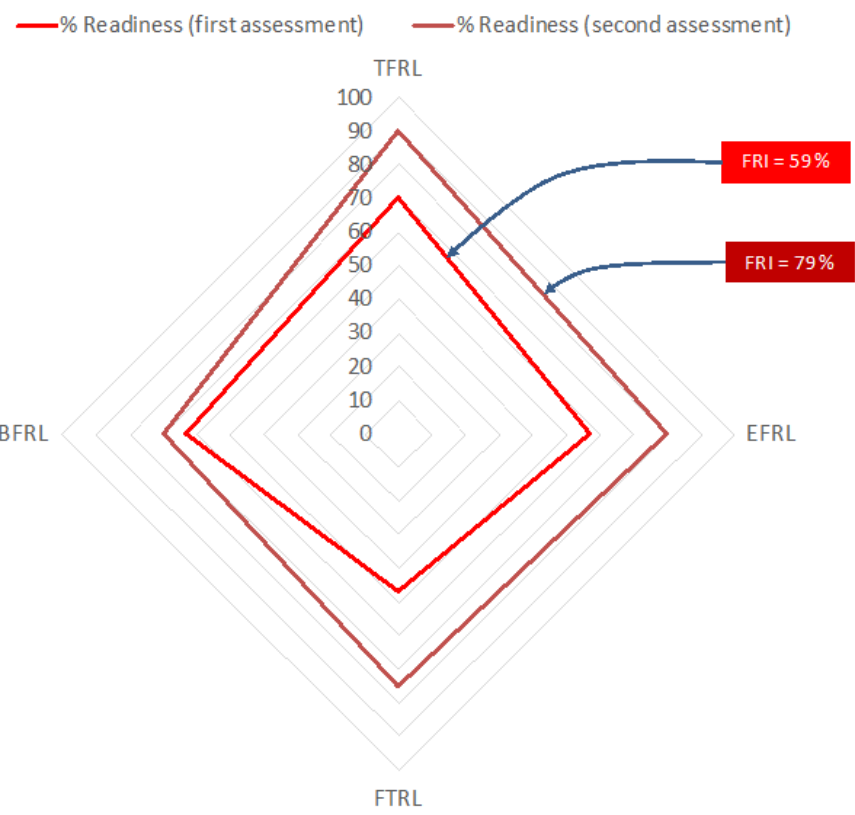

Figure 13: Future readiness index based on performance against FRLs

\section{VALIDATION}

The concepts used in the conceptual future readiness model discussed above were validated in a survey.

\subsection{The survey respondent profile}

The survey was conducted among respondents who included business owners, board members, Csuite executives (CEO, COO, CTO, etc.), senior management, project managers, researchers, 
academics, and government officials. Thirty-six respondents provided their inputs. The age distribution was from 20 to over 60 , with the majority (39\%) of the respondents being between 51 and 60 years of age, followed by an almost equal spread between 31 and 40 and between 41 and 50 . About 15 per cent of the respondents were over 60 years of age. Ninety-four per cent of the respondents indicated that they are often confronted in their work context with the need to make decisions about the future. Eighty-six per cent of the respondents had previously worked with TRLs, 31 per cent with MRLs, and 36 per cent with capability maturity model integration. This indicates that the majority had worked with readiness levels of some kind, and some of them with more than one type.

\subsection{The FRLs}

There was agreement that the FRLs, as presented in the conceptual model, were relevant. The levels that were tested for each of the TFRL, BFRL, EFRL, and FTRL were deemed essential and important. Very few of the levels presented to be evaluated were seen as marginal, and only a few of the EFRLs were considered 'not required' by a minority of the respondents. This validates the choice of FRLs presented in this paper. The respondents were not asked to provide the sequence of measurement as outlined in the conceptual model. This sequence is part of a natural development and learning process suggested by the author.

\subsection{The FRL audit questions}

The respondents were asked to validate the audit questions suggested in the conceptual model (section 4.2.1). Agreement with all the questions was above 70 per cent. Only the question about identifying documents/procedures/policies that provide evidence of future readiness levels was supported by just under 60 per cent of the respondents.

\section{FUTURE SHAPING INFLUENCES FOR INDUSTRY 4.0 READINESS}

Respondents were asked to rank future shaping influences (technology, behaviour, and events) that will guide the measurement of future readiness for Industry 4.0. The influences are illustrated in the future thinking space in Figure 14 in the order of importance revealed by the research.

When thinking of future readiness for Industry 4.0, these factors must be considered closely, and an assessment must be made on future readiness to deal with those that will impact the core business of an enterprise. This mapping of the ten prevailing influences on each future influencing factor (technology, behaviour, events) for Industry 4.0, and the perception of the respondents of the importance of each, will have to be borne in mind when considering readiness for the era of Industry 4.0.

\section{CONCLUSIONS}

A conceptual model for future readiness measurement was presented in this paper. Future readiness levels were introduced along the line of technology and manufacturing readiness levels. An approach was presented on how to audit the enterprise for future readiness, and on how to make an assessment at the level of technology, behaviour, and events as future shaping factors in the future thinking space. There is limited literature on the measurement of future readiness, and most articles address maturity model approaches. It is argued in this paper that a maturity assessment may follow an initial future readiness assessment based on readiness levels, as outlined. The FRI that is proposed is a useful indicator of progress towards future readiness at enterprise (organisation), industry, and national level.

The research paid specific attention to applying future readiness measurement in Industry 4.0 as a fast-approaching era. The future shaping factors for Industry 4.0 were validated and ranked in terms of their importance. This provides a view of the technologies, behaviours, and events that enterprises need to get under control when they venture into the Industry 4.0 paradigm. The opinions of survey respondents were probed about adopting a future readiness approach. Feedback indicated that scepticism and practicality will be a hindrance to applying future readiness 


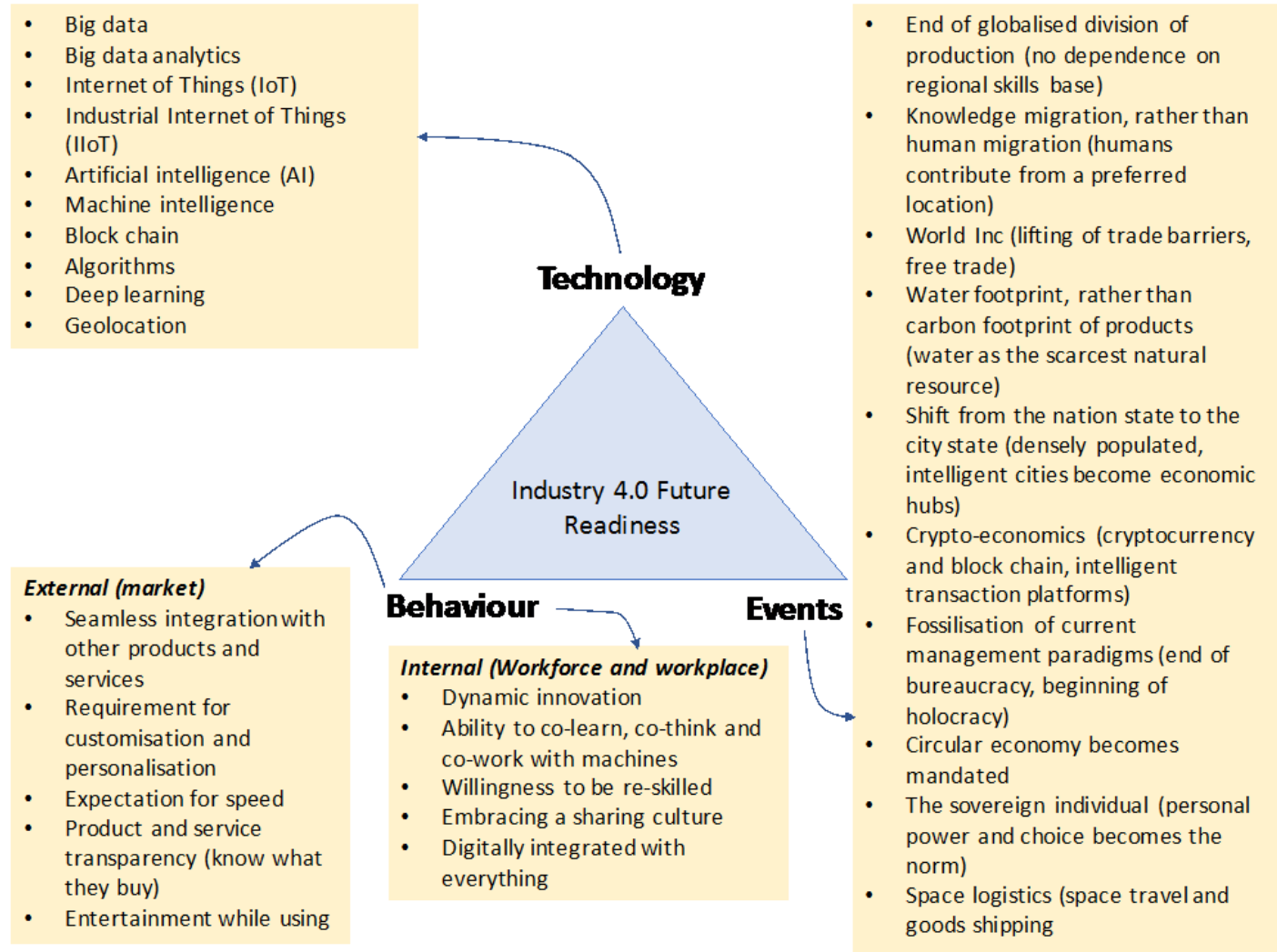

Figure 14: Future shaping factors that determine the readiness for Industry 4.0 (ordered from high impact to low impact)

measurement. Since it is closely associated with future thinking capabilities, a skill that is not well developed in executive and senior management, the adoption of FRLs and future readiness assessment processes may be slow.

This lethargy is exacerbated by the fact that the future will most probably see big companies leveraging existing assets and management approaches. Many entities will be faced with the question of what else to do with their assets, rather than aligning them with Industry 4.0. To a large extent, there is a spirit of denial and avoidance of Industry 4.0 among older industries, as a radical new wave and gradual migration towards applying Industry 4.0 philosophies is expected, rather than a rapid and abrupt change. One of the greatest problems with adopting a highly dynamic environment is that people become reactive rather than pro-active. Attention should be given to developing decision-makers and managers to lead and guide the action and to deal with it adequately and efficiently to maximise opportunities arising from it. The focus is often on correcting inefficiencies and chasing existing opportunities to improve what is currently being done in organisations, instead of chasing new trends and losing the opportunity to add value with what is known.

Regardless of these barriers to progress, future readiness measurement provides a way to assess the impact of a rapidly arriving future to both those who are conservative about change and the proponents of rapid progress. For both, a method is suggested to measure their readiness for transition from a known era to one that is new and exciting, but unknown. Decision-making can now be done on a thorough future readiness assessment, making use of FRLs, and informed decisions can be taken on the pace of change or adoption of Industry 4.0 philosophies and processes. The adoption of a future thinking mind-set within organisations requires buy-in from various levels, but it is often opposed because the concepts are not understood; hence the fear of the unknown becomes a stumbling block. Future readiness measurement provides a handle on this uncertainty, and may be the catalyst for adopting future thinking. 
Eventually, all organisations - regardless of the industry in which they operate, and where they contribute to the value chain - need to adapt to Industry 4.0 factors that shape and influence their environments, and need to condition their human resource assets to embrace the technological revolution.

\section{RECOMMENDATIONS}

This research paper is of a conceptual nature. The FRLs suggested and validated in the preliminary research reported on must be tested in practice to confirm, modify, and improve them. The audit and assessment processes need to be applied to judge their practicality. Further research is required on the transition between the use of readiness levels and maturity models. Solid academic debate and pro-active industry application is required. It is recommended that the ideas communicated in this paper be scrutinised in academic debate, and be taken up by technology and engineering managers to start preparing their organisations for entering Industry 4.0. The emergence of Industry 4.0 is unavoidable; it has arrived, and it is influencing the way business is conducted in a broad context. Denying it will not mean escaping it. Getting a handle on readiness to become involved in a future phenomenon is a crucial skill, and the tools suggested may be the beginning of making it possible for organisations not only to survive, but also to thrive, in Industry 4.0.

\section{REFERENCES}

[1] PWC Global Industry 4.0 Survey. 2016. Industry 4.0: Building the digital enterprise, available at: https://www.pwc.com/gx/en/industries/industries-4.0/landing-page/industry-4.0-building-your-digitalenterprise-april-2016.pdf (accessed 12 June 2018).

[2] McKinsey \& Company. 2015. Industry 4.0 - How to navigate digitization of the manufacturing sector, available at:

https://www.mckinsey.com/ /media/McKinsey/Business\%20Functions/Operations/Our\%20Insights/Indust ry\%2040\%20How\%20to\%20navigate\%20digitization\%20of\%20the\%20manufacturing\%20sector/Industry-40How-to-navigate-digitization-of-the-manufacturing-sector.ashx (accessed 12 June 2018).

[3] US Department of Energy. 2013. Office of Environmental Management, Technology Readiness Assessment (TRA)/Technology Maturation Plan (TMP) Process Implementation Guide, Revision 1, available at:

https: / / www.energy.gov/sites/prod/files/2014/03/f12/ATTACHMENT-TRA\%20Guide\%20\%20\%209-3-13.pdf (accessed 12 June 2018).

[4] US Department of Defence. 2011. Manufacturing Readiness Level (MRL) Deskbook Version 2, OSD Manufacturing Technology Program, in collaboration with The Joint Service/Industry MRL Working Group, available at:

http://static1.squarespace.com/static/55ae48f4e4b0d98862c1d3c7/t/55df0e7ee4b05aef5ffbb5b2/14406 81598134/MRL_Deskbook_V2.pdf (accessed 12 June 2018).

[5] Schumacher, A., Erol, S. and Sihn, W. 2016. A maturity model for assessing Industry 4.0 readiness and maturity of manufacturing enterprises, Procedia CIRP 52, pp. 161-166.

[6] Lichtblau, K., Stich, V., Bertenrath, R., Blum, M., Bleider, M., Millack, A., Schmitt, K., Schmitz, E. and Schröter, M. 2015. Industrie 4.0 Readiness, VDMA, Foundation for Mechanical Engineering, Plant Engineering and Information Technology, available at:

https: / /industrie40.vdma.org/documents/4214230/5356229/Industrie\%204.0\%20Readiness\%20Study\%20En glish.pdf/f6de92c1-74ed-4790-b6a4-74b30b1e83f0 (accessed 12 June 2018).

[7] Rockwell Automation. 2014. The connected enterprise maturity model, available at: http://literature.rockwellautomation.com/idc/groups/literature/documents/wp/cie-wp002_-en-p.pdf (accessed 12 June 2018).

[8] Botha, A.P. 2016. Developing executive future thinking skills, International Association for Management of Technology (IAMOT) Conference Proceedings, Orlando, Florida, USA, pp. 951-972.

[9] Botha, A.P. 2016. Future thinking in R\&D management, R\&D Management Conference "From Science to Society: Innovation and Value Creation", Cambridge, UK, pp. 1-13.

[10] Botha, A.P. 2017. Machine innovation - A future reality? International Association for Management of Technology (IAMOT) Conference Proceedings, Vienna, Austria, pp. 1-16.

[11] Botha, A.P. and Pretorius, M.W. 2017. Future thinking - The scarce management skill, Portland International Centre for Management of Engineering and Technology (PICMET), pp. 1-9.

[12] European Space Agency. 2008. Technology Readiness Levels Handbook for Space Applications, TECSHS/5551/MG/ap, available at: https://artes.esa.int/sites/default/files/TRL_Handbook.pdf (accessed 12 June 2018).

[13] Straub, J. 2015. In search of technology readiness level (TRL) 10, Aerospace Science and Technology, 46, pp. 312-320. 